\title{
SCIENTIFIC SUBSTANTIATION OF THE CONCEPTION OF CONTINUOUS ECONOMIC EDUCATION DEVELOPMENT
}

\author{
Sergeeva Marina Georgievna ${ }^{1}$, Bondarenko Natalia Grigorievna ${ }^{2}$, Shebzuhova Tatiana Alexandrovna ${ }^{3}$, \\ Vartumyan Arushan Arushanovich ${ }^{4}$, Lesnikova Svetlana Leonidovna ${ }^{5}$ \\ ${ }^{1}$ Doctor of Pedagogic Sciences (Advanced Doctor), Associate Professor, Professor at the Department of \\ Social Pedagogy, Institute of Foreign Languages, Peoples' Friendship University of Russia \\ ${ }^{2}$ Doctor of Philosophical Sciences, Professor, the Head of Department of History and Philosophy of \\ Law of the Institute of Service, Tourism and Design FGAOU VPO «North-Caucasus Federal \\ University» in Pyatigorsk \\ ${ }^{3}$ Doctor of Historical Sciences, Professor, Director of the Institute of Service, Tourism and Design \\ (branch) FGAOU VPO «North-Caucasian Federal University» in Pyatigorsk \\ ${ }^{4}$ Institute of Service, Tourism and Design of North Caucasus Federal University \\ ${ }^{5} \mathrm{PhD}$ in Pedagogy, Associate Professor, Associate Professor at the Inter-University Department of \\ General and Higher Education Pedagogy, Institute of Education, Kemerovo State University
}

\begin{abstract}
The Conception of continuous economic education development developed by us is based on the idea of continuous education, in which economic education is considered as an important structural element in the conditions of the new Russian developing economy. As a result of Russia's transition to a market economy, there is an urgent need for economic training of specialists who successfully work in the new socio-economic conditions, quickly and adequately responding to the changing market conditions. Economic education is aimed at the formation of economic competencies (key, professional and additional), and economic training is carried out in order to: the formation of economic thinking; development of business qualities of an economically educated person; accumulation of knowledge in the field of economy, management, taxation. In the conditions of market type economy professional education is focused on formation of the competitive, demanded in the labor market specialist possessing necessary economic competences which are formed in the course of economic training and economic education including knowledge of the objective economic laws and categories system; formation of economic competences and their realization in economic behavior; development of business qualities of the economically educated person; accumulation of knowledge in the field of economy, management, and taxation. The analysis of the classifications of competencies on various grounds allowed us to develop a structure of economic competence of students, including key, professional, and additional economic competences. The Conception of continuous economic education development developed by us takes into account the idea of continuing education, in which continuing economic education becomes an important structural element of vocational education in the conditions of the new Russian developing economy.
\end{abstract}

Keywords: scientific substantiation, economic education

\section{INTRODUCTION}

Conception or concept (from Latin conceptio - understanding, system) is understood as a general plan, a guiding idea that determines the action strategy, or a system of views on phenomena in the world, in nature, in society. The conception is a certain way of understanding (interpretation, perception) of any object, phenomenon or process; the main point of view on the subject, the guiding idea for its systematic coverage, a set of views related to each other and arising from one another, a system of ways to solve the selected problem [2].

The Concept of continuous economic education development developed by us is based on the idea of continuous education, in which economic education is considered as an important structural element in the conditions of the new Russian developing economy. The need to develop the conception is justified by such factors as the current requirements of employers to the labor market, the developing market of 
educational services, the need for social partnership, features and specifics of the regional educational policy.

Systemic changes have been initiated in Russian education aimed at ensuring its compliance with both the innovation economy requirements and the society demands. At the same time, the priority directions in this sphere are to bring the content and structure of vocational training in accordance with the modern needs of the labor market.

In the works of A.M. Novikov [10], T.Yu. Lomakina [7] it is stated that in modern conditions the Conception of continuing professional education should be considered as an instrument of economic policy aimed at improving competitive ability, achieving fuller employment, ensuring professional mobility of workers in connection with the implementation of new technologies and is based on the following general pedagogic principles: basic education, multilevel, diversification, complementarity of basic and postgraduate education, maneuverability, continuity, integration of educational structures, flexibility of organizational forms.

\section{METHODOLOGY OF RESEARCH}

The first conceptual position of our research is that the idea of continuing education in the conditions of scientific and technological progress and changing conditions of social life in relation to economic education in the vocational education system provides for the mandatory development and replenishment of economic knowledge, making a person confident in any situation of reality and contributing to his development as a subject of activity throughout life.

As a result of the country's transition to a market economy, there is an urgent need for economic training of specialists who are successfully working in the new socio-economic conditions, quickly and adequately responding to the changing market conditions.

The second conceptual position of the study is that continuing economic education is a part of continuing professional education, which is focused on the formation in the market type economy competitive, demanded in the labor market specialist, and involves the formation of his economic competencies in training profiles at different levels of vocational education in the process of training and education. At the same time, economic training is aimed at the formation of economic competencies (key, professional and additional), and economic education is carried out in order to: formation of economic thinking; development of business qualities of an economically educated person; accumulation of knowledge in the field of economy, management, and taxation.

There are different approaches to defining the essence of economic training. Education is the result of training. Training, in turn, according to I.P.Pidkasisty, is "a specially organized, goal-oriented and controlled process of interaction between teachers and students, aimed at the assimilation of knowledge, abilities, skills, the worldview formation, the development of students mental strength and potential, the consolidation of self-education skills in accordance with the objectives" [11, p. 26]. All this fully applies to economic training.

Education in general "is the amount of systematic knowledge, abilities, skills, and ways of thinking which the learner has mastered" [11, p. 27]. Based on this, economic education is a set of economic knowledge, abilities, skills acquired by students in the learning process.

So, scientists B.P. Shemyakin, P.A. Shemyakin and V.K. Rozov consider that economic education acts as "qualitative characteristic of economic knowledge, abilities and skills of school students ..." [13].

According to L. Lyubimov "economic education is one of the important sources of formation of human behavior, understanding and recognition of certain "rules of the game", "on trust" acceptance of this or that system of value attitudes and orientation. Such education, unlike the study of many other fields "knowledge" is necessary always and everywhere for anyone, because it "equips" a person's life, and the absence of such education makes a person unprotected, deprived of a significant part of adaptive capacity" [8]. 
Today economic training is aimed at mastering a certain amount of knowledge on the economy by students, adequate to modern reality; mastering the skills of adaptation to social roles in an everchanging economic environment; creating a basis for further, more in-depth study of economic science; formation of a high level of economic thinking and instilling skills of rational economic behavior, the creation of prerequisites for further professional training and effective practical activity [4].

In the process of research we identified the causes and circumstances of the active appeal of the national pedagogical science and practice to the problems of economic education: the urgent need to develop and transfer the economy to a higher level; the requirement of establishing economic relations and economic training of participants in economic processes. The genesis of the main stages of economic thought in Russia, generalized by A.S. Bulatov [1] allowed revealing the theoretical assumptions of modern economic education:

- the multicountry nature of the Russian economy determined by the constant expansion of its territorial borders, which ended with the creation of the world's largest Eurasian state;

- the economic existence of national schools, which were built fundamentally different in contrast to the west, the relations of state and society;

- the national policy on the principle of unity of economic education and training which provides training of highly qualified specialists. At the same time, the basis of competitiveness, economic growth and economic efficiency is not equipment and production reserves, but human national Russian "capital";

- the influence of spiritual culture as a carrier of historical memory of the people on the system of ideas and values, the definition and choice of the economic thought structure;

- the economic life of the Russian society, including the relations arising between all its members in the process of production, distribution, exchange and consumption of material goods;

- the gradual development of modern economic thought that contributed to the emergence of a new direction in economic science - "Economix" on the micro - and macro - levels, and fundamentally different from the rate of the Marxist-Leninist political economy: on traditional political economy the market organization has no future, on "Economix" there is no sense in the organization of the social economy, except the market one.

The development of continuing economic education is influenced by the following factors: socioeconomic environment (high rate of obsolescence of professional knowledge; reduction of unskilled and low-skilled labor sphere; structural changes in employment; changes in demand from the state, the individual, the labor market and the service sector; limited time and material resources of the individual) and socio-pedagogical conditions (focus on education and self-education throughout life; construction of continuous economic education on a fundamental basis; multilevel structure of economic education; variability of educational programs; readiness of the individual for social dynamics; variability of the structure and volume of specialists training; adaptability of educational levels) [5].

Education in a broad pedagogical sense is "a specially organized, purposeful and controlled impact of the collective, educators on the praised with the purpose of forming his/her specified qualities, carried out in educational institutions and covering the entire educational process [11].

One of the components of the holistic educational process is economic education. Under the economic education is understood as "the purposeful interaction of teachers and pupils, aimed at the formation of the latter knowledge, abilities, skills, needs, interests, style of thinking, appropriate to the nature, principles and rules of good management and organization of production, distribution and consumption" [3].

V.S. Selivanov believes that "economic education is the implementation of students in the world of economic relations, budget, financial calculations, forms of ownership and economic relations" [15]. According to B.T. Likhachev economic education "is an organized pedagogical activity, a specially designed system of work aimed at the formation of the economic consciousness of students. ... Economic education ensures the development of economic thinking, the formation of moral and business qualities that are formed in economic activity ..." [6]. Teachers V. K. Rozov, B.P. Shemyakin, P.A. Shemyakin by economic

Submit Date: 10.01. 2018, Acceptance Date: 23.02.2018, DOI NO: 10.7456/1080MSE/122

Research Article - This article was checked by Turnitin

Copyright (C) The Turkish Online Journal of Design, Art and Communication 
education understand preparation of the person for economic activity, to conscious participation in economic life of society. "Economic education serves as the basis for the formation of economic thinking" [13].

At the same time, it should be noted that many authors do not distinguish clearly the concepts of "economic education" and "economic training". This line is very difficult to draw as in teaching we are training and in educating we are teaching. Thus, I.A. Sasova defines "socio-economic training and education of children and students". It involves the inclusion of the latter "... in the social and economic relations peculiar to modern production, educating at them needs to be guided in their activity not only personal, but also public interests, to increase efficiency of production, distribution, exchange and consumption of material and spiritual goods. It is also education of a way of thinking, behavior and activity corresponding to economic and moral and legal bases of society, the economic relation to all types of property" $[14,17,18,19]$.

Economic education as a process is a purposeful pedagogical influence of other persons (parents, teachers, communities, etc.) on the formation of certain economically significant personality traits.

Economic education as a result there is an integral integrity, formed from beliefs, principles, skills, traditions, customs, based on economic knowledge and human culture. Economic education is expressed in behavioral, emotional, active characteristics of people, necessary for effective life and effective adaptation to changing living conditions.

\section{RESEARCH RESULTS}

In our research, considering the continuous economic education as a mandatory part of continuing professional education, we prove that it is focused on creating a competitive, in demand on the labour market specialist in conditions of market type economy, possessing the necessary economic competences, which are formed in the process of economic training and economic education, including the knowledge of the system of objective economic laws and categories; the formation of economic competences and their implementation in economic behavior; development of business qualities of an economically educated person; accumulation of knowledge in the field of economy, management, and taxation.

Therefore, the third conceptual position of the research is that in the content of economic education economic competence is a necessary and mandatory part of the training of any specialist in the vocational education system, which is due to: the labor market development, where there are both economic giants and enterprises of medium and small businesses, whose share will increase; inflation, economic reforms (pension, housing, etc.), paid educational and medical services, involvement of a working citizen in the formation of the personal and family budget.

The Conception of continuous economic education development developed by us represents the system of components: scientific and methodological (principles of economic training and economic education, essence and content of the principle of economic competence), processual (applied model of formation of the graduate economic competences) and verification of process of formation of economic competences of the graduate of professional education organization.

Within the framework of the scientific and methodological component of the Conception, we clarified the concepts of "competence", "competency" and "professional competency" and analyzed the state educational standards of three generations. The analysis of the literature allowed to define competence as an integral personal and professional quality of the person who finished a certain stage education, expressed in readiness and ability on its basis to successful, productive and effective activity taking into account its social significance and social risks which can be connected with it; providing the opportunity of effective interaction with the surrounding world by means of the corresponding competencies. Competencies are an open system of knowledge, abilities, skills that are acquired in the educational process and corrected during the period of practical activity. The feasibility of implementing the concept of "professional competency" is due to the breadth of its content, integrative characteristics, combining such commonly used notions as "professionalism", "qualification", "professional ability",

Submit Date: 10.01. 2018, Acceptance Date: 23.02.2018, DOI NO: 10.7456/1080MSE/122

Research Article - This article was checked by Turnitin

Copyright (C) The Turkish Online Journal of Design, Art and Communication 
etc. In our study, we define professional competency as an integral personal education, which combines the value understanding of social reality, categorical specific professional knowledge, acting as a guide to action, the subjective ability to self-determination, the personal ability to implement professional technologies in the main areas of human activity.

The analysis of the state educational standards (SES) of three generations revealed:

- the features of SES of the first generation (the obligatory minimum of the maintenance of the main educational programs; the maximum volume of the academic load of students; requirements to the level of preparation of graduates);

- the features of SES of the second generation (accounting of tariff and qualification characteristics of the Labor Ministry of Russia at forming of requirements to graduates; coordination of requirements to graduates and the maintenance of education with Federal Executive Authorities; simultaneous development of SES for all levels of education; development of standards for "enlarged" directions of preparation of the certified specialists in the field of equipment and technology);

- distinctive features of Federal State Educational Standards (FSES) of the third generation from the previous SES (limited regulation; independence of the educational program; modular organization of programs; competencies as an educational result; orientation to requests of the labor market). FSES provides a clear definition of the concept of "Competency - the ability to apply knowledge, skills and personal qualities for successful activities in a particular area" [9]. The logic of this concept in relation to the field of vocational education is that the student receives a certain amount of basic (theoretical) knowledge on the chosen specialty profile; a set of methodologies and techniques for the application of this knowledge in practice; a certain experience of such use (in the course of educational, industrial and other practices, laboratory and independent work, etc.), all these parameters should be evaluated equally. Competencies are divided into professional (specialization in certain areas) and universal (necessary for an educated person regardless of the profile of training).

\section{CONSIDERATION}

Our research showed that the implementation of the third generation standards takes into account the competence approach and is based on:

- the changes occurring in the labour market (redirection of the demand for new skills and changes in work organization; decline in demand for unskilled manual labor; the proliferation of automated control systems of production processes; the decline of mass production; the increase of individual responsibility of employees for quality of work; the increase of the level of interaction between employees in the team; the blurring of the boundaries between the professions);

- new requirements for the training of specialists (labor activity is formed around processes rather than operations; significant are non-technical aspects of labor - planning, coordination and communication, decision-making; adaptability as a leading indicator of the quality of specialist training);

- the mechanism of interaction of the labor market and the market of educational services at different levels (federal and regional) of management which assumes implementation of the state policy in the field of professional education and training of personnel; providing the developing labor market with the necessary volume of experts of the required profiles and qualifications taking into account the main trends of strategic development of economy of the region; rapid adaptation of vocational training institutions and retraining of personnel to changes in the labor market, improving human resources, professional mobility and competitiveness of employees;

- competence model of a graduate of a professional educational institution, congruent to developed structure of economic competence and containing seven blocks of competencies: educational, personal, intellectual, professional, communicative, information and economic. The unit of economic competencies is allocated by us in connection with the need of training of the expert possessing a certain level of economic knowledge and capable to make adequate decisions in various social and economic situations regardless of a specialty profile.

The scientific and methodological component of the Conception includes the system of private and pedagogical principles of economic training and economic education [12]: the illustrative models principle (image by means of the discipline of economic concepts, laws, systems that allows "economizing" the content for all general education subjects), the integrity principle (conscious need for scientific knowledge integration), the convergence principle (convergence of knowledge, abilities and

Submit Date: 10.01. 2018, Acceptance Date: 23.02.2018, DOI NO: 10.7456/1080MSE/122

Research Article - This article was checked by Turnitin

Copyright (C) The Turkish Online Journal of Design, Art and Communication 
skills in various academic disciplines contributes to the deep study of several subjects at the same time), the emergence principle (the creation of new knowledge and skills on the basis of the generated knowledge), the semantic turns principle (semantic turns on economic problems as a generalization of knowledge and interaction of the economy with other disciplines, representation of the real contribution of each subject to the disclosure of the economic content line).

The economic competence principle, which is a part of the scientific and methodological component of the Conception, establishes a relationship between knowledge as information and knowledge as an activity necessary for the formation of a competitive personality with a certain level of economic competencies in the process of vocational education. In determining the economic competence of the graduate of professional educational institution, we focused on the concept of "competence", "competency", "professional competence" that define terminology field of research and allow characterizing the notion of "economic competence of the graduate of professional educational institution".

Economic competence we consider as integral qualitative and professional characteristic of the person including the economic competences forming economically significant qualities of the person (competitiveness, initiative, mobility, ingenuity, independence in decision-making, critical thinking) and reflecting readiness and ability to carry out effectively professional activity in various spheres and segments of economy by means of building of the professional career, based on their individual values and projecting them in accordance with the strategy of development of society, moral grounds and rules. At the same time, economic competences are an open system of knowledge, abilities, skills, experience of practical economic activity and personal responsibility, which is activated and replenished in the process of professional activity as real economic problems that a graduate of a professional educational institution faces arise.

The analysis of competences classifications on various grounds (context of the solved tasks: general cultural and professional; level of distribution of competences: corporate, managerial, professional; level of development: threshold, differentiating; essence and content: cognitive, personal, functional, social, etc.) allowed us to develop the structure of economic competence of students, including the following economic competences:

- key - basic economic knoweledge necessary to adapt to market conditions;

- professional - the ability to apply economic knowledge in practice, the ability to assess new economic situations and make optimal economic decisions on them;

- additional - the ability of creative economic behavior, effective behavior in the labor market, continuous economic self-education, etc.

The basis for the selection of this structure of economic competence was the selection of the content of the modules of the studied disciplines: general humanitarian and socio-economic disciplines - key competencies; general professional disciplines - professional competencies; special disciplines (professional modules) - additional competencies.

Thus, the fourth conceptual position of the research is in the fact that the principle of economic competence, which is well-founded and meaningfully disclosed by us, states that in the process of continuous economic education a competitive person is formed in the system of professional education, possessing a certain level of economic competences necessary for performing professional activity in various spheres and segments of the economy.

\section{CONCLUSION}

As a result of the conducted research, we have identified the levels of continuous economic education in the system of vocational education (basic, professional, additional), which allow students after completing their studies at a certain level to perform the necessary labor actions and hold the appropriate positions.

The aim of the basic level of economic education in the vocational education system is the formation of knowledge and motives of competent consumer behavior in the market economy, the formation of differentiated initial knowledge on the economy with the ability to use them in everyday life. 
The aim of the professional level of economic education in the vocational education system is to prepare students to take ordinary positions that require professional economic training (timekeepers, technicians-quantity surveyors, accountants, secretaries, etc.).

The aim of the additional level of economic education in the vocational education system is to prepare graduates for direct practical economic activity in the context of creative approach: in the areas of marketing, advertising, trade; analysis of economic activity of enterprises; identifying reserves of growth, drawing up plans and forecasts; generating effective ideas in unusual economic situations; teaching in the field of economic disciplines; research activities.

Therefore, the fifth conceptual position of the research is that the levels of continuing economic education (basic, professional, additional) developed by us in the vocational education system are congruent to economic competencies (key, professional, additional) and assume the transition from one stage of economic education to another, preserving the continuity, universality, integrity of vocational education, taking into account the psychological and age-related personal development, providing graduates after finishing the training at a certain level of continuing economic education for holding relevant positions.

The Conception of continuous economic education development developed by us considers the idea of continuous education in which continuous economic education becomes an important structural element of professional education in the conditions of the new developing economy of Russia; is based on modern requirements of employers to the labor market, requirements of the social sphere to quality of education; it is revealed by the principle of economic competence and the model of formation of economic competencies of the graduate (key, professional and additional) on the profiles of training (economic and non-economic) and at different educational levels in accordance with the models of graduate and teacher; implemented in practice through a mechanism involving the relationship and interaction of economic training, economic education and inclusion of the individual in real economic activity.

\section{REFERENCES}

1. Bulatov A.S. Economics: textbook/A.S. Bulatov. - Moscow: INFRA - M, 2005. - P. 897.

2. Wikipedia. http://ru.wikipedia.org.

3. Kodzhaspirova G.M., Kodzhaspirov A.Yu. Pedagogical dictionary. For students of higher and secondary educational institutions. - Moscow: Publishing center "Academy", 2001.- 176 p. P. 32.

4. The conception of modernization of education until 2010 // Secondary vocational education. Collection of normative legal documents. / Comp. P.F. Anisimov, T.D. Barer, A.L. Kolomenskaya, etc. Under the editorship of P.F. Anisimov/Institute of development of vocational education of the Ministry of Education. M., 2004. 450.

5. Koshkina N.B. Multi-level professional training of specialists in the labor market: Dis. ... Can. Ped. Sciences, Kemerovo, 2007. 251 p..

6. Likhachev. B.T. Pedagogy. Course of lectures. Textbook. - Moscow: Yurayt, 1998. - 523 p. P. 284.

7. Lomakina T.Yu. Modern principle of continuous education development. M: Science, 2006. -221 p. 146

8. Lyubimov L. The Conception of structure, content and organization of economic education in high school//Economy in school. - 2002. - No. 3. P. 14-28.

9. Maksimov N.I. SES-3: define a thesaurus: [conversation with the Vice-rector on academic affairs of Moscow State Textile University N. Maksimov] N.I. Maksimov // Accreditation in education. - 2007. - N 12. P. 56-57.

10. Novikov A.M. Post-industrial education. - M.: Publishing House "Egves", 2011.

11. Podlasy I.G. Pedagogy: textbook for students of higher pedagogical educational institutions. - M.: Education: VLADOS, 1999. - 576 p.

12. Popova N.E. Inheritance for "Our New School" // "Economics at school". No. 1(55) 2011. P. 11-24.

13. Rozov V.K., Shemyakin B.P. Methodology of schoolchildren economic education: textbook for a special course for students of pedagogical universities. - M.: Education, 1985. - 165 p. - P. 15.

Submit Date: 10.01. 2018, Acceptance Date: 23.02.2018, DOI NO: 10.7456/1080MSE/122

Research Article - This article was checked by Turnitin

Copyright $\odot$ The Turkish Online Journal of Design, Art and Communication 
14. Sasova I.A. Socio-economic training and education of students // National education, 2001. No. 10. - P. 165.

15. Selivanov V.S. Fundamentals of general pedagogy: Theory and methods of education. Moscow: publishing center "Academy", 2000. - 336 p. - P. 24.C

16. Economic theory at school. Book for teachers. - R-on-D: Phoenix Publishing house, 1996. $544 \mathrm{p}$.

23. 17. Bulganina S.V., Ivanova D.S., Shutova Yu.G. Sociological survey of students on the organization of independent work in the university // Modern Science Success. 2017. V.1 №4. P. $7-10$.

18. Ermakova E.V., Slizkova E.V., Kungurova I.M. Adaptation of first-year students in local pedagogical university // Modern Science Success. 2017. V.1 №4. P. 121 - 126.

19. Bratukhina E.V. Social and professional responsibility of personality as a pedagogical problem // Modern Science Success. 2017. V.1 №4. P. 199 - 203. 